\title{
ANALISIS METODE JOB ORDER COSTING DALAM MENENTUKAN HARGA POKOK PRODUKSI PADA SRADA LAMP'S DI GIANYAR
}

\author{
Yuhana Dewi ${ }^{1}$, Lulup Endah Tripaupi ${ }^{2}$, Anjuman Zukhri ${ }^{3}$ \\ Jurusan Pendidikan Ekonomi Uni \\ versitas Pendidikan Ganesha \\ Singaraja, Indonesia \\ e-mail: yuhana.ayu30@gmail.com ${ }^{1}$, tripalupilulup@gmail.com², \\ anjuman.zukhri@yahoo.co.id ${ }^{3}$
}

\begin{abstract}
Abstrak
Penelitian ini bertujuan untuk mengetahui unsur perhitungan harga pokok produksi yang dilakukan Srada Lamp's, perhitungan harga pokok produksi dengan penerapan metode job order costing pada Srada Lamp's, dan perbedaan perhitungan harga pokok produksi yang digunakan Srada Lamp's selama ini dengan perhitungan yang dilakukan berdasarkan metode job order costing. Penelitian ini merupakan penelitian dekriptif kuantitatif. Data dikumpulkan dengan metode dokumentasi yang dianalisis menggunakan metode job order costing. Hasil penelitian menunjukka $\mathrm{n}$ bahwa unsur perhitungan harga pokok produksi yang digunakan Srada Lamp's dalam menentuka $\mathrm{n}$ harga pokok produksi yaitu biaya bahan baku dan biaya tenaga kerja langsung, pada perhitunga $\mathrm{n}$ harga pokok produksi menggunakan job order costing biaya bahan baku, biaya tenaga kerja langsun $\mathrm{g}$, dan biaya overhead dihitung untuk setiap pesanan, sehingga harga pokok produksi lebih ting gi dibandingkan perhitungan yang dilakukan Srada Lamp's dan selisih harga pokok produksi yai tu lampion ukuran kecil $(50 \mathrm{~cm} \times 15 \mathrm{~cm}$ ) berbentuk bulat Rp. 8.004,25, bentuk love Rp. 12.873,8 3 Lampion ukuran sedang $(70 \mathrm{~cm} \times 15 \mathrm{~cm})$ bentuk bulat Rp. 1.832,85 bentuk oval Rp. 2.799,52. u ntuk lampion 2 lampu bentuk bulat Rp. 38.518,10, bentuk oval Rp. 38.735,25. sedangkan lampion 3 la mpu bentuk bulat Rp. 3.060 bentuk kuncup Rp. 24.108,22 bentuk oval Rp. 26064,50.
\end{abstract}

Kata kunci: harga pokok produksi, job order costing, biaya produksi.

\begin{abstract}
This study aims to know the element of calculation cost of goods manufactured by Srada Lamp's the calculation of cost of goods manufactured for the determination of cost of goods sold by using job order costing method the difference of calculation result of cost of goods manufactured in Srada Lamp's factory by job order costing method. The type of this research was descriptive quantitativ e. Data were collected by documentation method which are analyzed by job order costing method. The result showed that the element of calculation cost of goods manufactured by Srada Lamp's factory was by calculating the cost of raw materials and direct labor costs. The calculation of

cost of production using job order costing calculates the cost of raw materials, direct labor costs and variable factory overhead costs. so that the cost of production was higher than the calculation of Srada Lamp's and there was a difference in cost of goods manufactured for small sized lampion $(50 \mathrm{~cm} \times 15$ $\mathrm{cm})$ in round shape $\mathrm{Rp} .8 .004,00$, in heart shape $\mathrm{Rp}$. 12.873,83,. For medium sized lampion $(70 \mathrm{~cm} x$ $15 \mathrm{~cm}$ ) in round shape Rp. 1.832,85, in oval shape Rp. 2.799,52. For lampion with 2 lamps in rou nd shape Rp. 38.518,10, in oval shape Rp. 38.735,25. Whereas for lampion with 3 lamps in roun d shape Rp.

3.060,00 in bud Rp. 24.108,22, in oval shape Rp. Rp. 26064,50.
\end{abstract}

Keyword: cost of good manufactured, job order costing, production cost 


\section{PENDAHULUAN}

Biaya adalah pengorbanan sumber ekonomis yang diukur dalam satuan uang yang telah terjadi atau kemungkinan akan terjadi untuk mencapai tujuan tertentu (Bustomi, 2002). sedangkan menurut Dunia (2009:22) "biaya adalah pengeluaran-pengeluaran atau nilai pengorbanan untuk memperoleh barang atau jasa yang berguna untuk masa yang akan datang, atau mempunyai manfaat melebihi satu periode tahunan, biasanya tercermin dalam neraca sebagai aset (asset) perusahaan". Biaya dapat diklasifikasikan menjadi beberapa kelompok. Klasifikasi biaya atau pengelompokkan biaya ini diperlukan untuk membantu manajemen dalam mencapait ujuannya. Menurut Daljono (2011) biaya d apat diklasifikasikan dalam tiga klasifikasi, y aitu klasifikasi biaya berdasarkan $\mathrm{h}$ ubungannya dengan produk, klasifikasibi aya berdasarkan, dan klasifikasi biaya $b$ erdasarkan volume produksi.

Berdasarkan hubungannya dengan produk, biaya dapat dikelompokkan menjadi biaya pabrikasi dan biaya komersil. Biaya pabrikasi disebut juga sebagai biaya produksi atau biaya pabrik, sedangkan biaya komersil adalah biaya yang terdiri dari biaya pemasaran dan biaya administrasi dan umum. Klasifikasi biaya berdasarkan waktu pengakuan, biaya diklasifikasikan menjadi biaya produk dan biaya periode. Biaya produk adalah biaya yang terjadi dalam rangka membuat produk. Biaya ini sifatnya melekat pada produk. Biaya produk akan dipertemukan dengan pendapatan pada periode dimana produk tersebut dijual, selama produk belum dijual biaya produk $t$ etap melekat pada produk. sedangkan Biaya periode adalah biaya yang terjadi dalam satu periode yang tidak ada kaitannya dengan pembuatan produk. Biaya periode sifatnya tidak melekat pada produk dan akan dipertemukan dengan pendapatan untuk menghitung laba rugi pada periode yang bersangkutan. sedangkan Berdasarkan volume produksi, biaya diklasifikasikan menjadi biaya tetap, biaya variabel, dan biaya semi variabel.

Biaya tetap adalah biaya yang secara total tidak berubah saat aktivitas bisnis meningkat atau menurun sepanjang kapasitas normal. Meskipun beberapa jenis biaya tampak sebagai biaya tetap, semua biaya sebenarnya bersifat variabel dalam j angka panjang. Satu jenis biaya tertentu s ebaiknya diklasifikasikan sebagai biaya te tap hanya dalam rentang aktivitas yang ter batas. Rentang aktivitas yang terbatas ini ser ing disebut rentang yang relevan (rel evant range). Biaya variabel adalah bia ya yang jumlahnya meningkat secara pro porsional terhadap peningkatan dalam akti vitas bisnis dan menurun secara pro porsional terhadap penurunan dalam akti vitas bisnis. Biaya variabel termasuk biay a bahan baku, tenaga kerja langsung. Biay a semi variabel adalah biaya yang mem perlihatkan karakter dari biaya tetap maup un biaya variabel. Karakteristik biaya semi variabel adalah biaya ini meningkat atau menurun sesuai dengan peningkatan atau penurunan aktivitas bisnis namun tidak prop orsional.

Biaya adalah unsur penting yang digunakan untuk menentukan harga pokok produksi. Harga pokok produksi merupakan suatu aspek yang sangat penting dalam perusahaan karena tanpa adanya perhitungan harga pokok produksi yang tepat dan benar maka perusahaan yang bersangkutan tidak akan mengetahui dengan pasti keuntungan yang diperolehnya. Harga pokok produksi adalah jumlah dari biaya bahan baku, biaya tenaga kerja langsung, dan biaya overhead pabrik yang digunakan untuk memproduksi suatu produk (Hansen \& Mowen, 2009). Menurut Carter (2009) Unsurunsur biaya yang digunakan untuk mene ntukan harga pokok produksi yaitu, biaya bahan baku, biaya tenaga kerja langsung, dan biaya overhead pabrik.

Biaya bahan baku adalah biaya perolehan semua bahan baku yang pada akhirnya akan menjadi bagian dari objek biaya (barang dalam peroses dan kemudian barang jadi) dan yang dapat ditelusuri ke objek biaya dengan cara yang ekonomis" (Dewi, 2015:21). sedangkan menurut Supriyono (2010) biaya bahan baku adalah 
harga perolehean dari bahan baku yang dipakai dalam pengolahan produk. Biaya ini timbul karena pemakaian bahan. Biaya bahan baku merupakan harga pokok bahan yang dipakai dalam memproduksi barang dan merupakan bagian dari harga pokok barang jadi diproduksi. Penilaian bahan baku yang digunakan dalam proses produksi dibuat sebagai biaya bahan baku, sedangkan besarnya nilai bahan penolong atau bahan pembantu disebut dengan biaya bahan penolong.

Tenaga kerja merupakan pelaku utama dalam produksi berupa pengeluaran biaya.

-biaya untuk gaji atau upah tenaga kerja. Biaya tenga kerja adalah biaya yang dibe bankan untuk penggunaan tenaga kerj a. sehingga, biaya tenaga didefinisikan seb agai biaya yang timbul akibat pen ggunaan tenaga kerja manusia untuk pen golahan produk. Biaya tenaga kerja adal ah harga yang dibebankan untuk peng gunaan tenaga kerja manusia tersebut. sedn gkan biaya tenaga kerja langsung adala $\mathrm{h}$

-pembayaran kepada para pekerja yang dia sarkan pada jam kerja atau dasar unit yan $g$ diproduksi (Abdul, 2010:73)

Biaya overhead pabrik adalah biaya pabrik selain dari bahan baku dan tenaga kerja langsung Biaya ini tidak dapat diidentifikasi secara langsung dengan barang yang dihasilkan perusahaan. Contohnya adalah bahan pembantu atau bahan tidak langsung (indirect materials), $t$ enaga kerja tidak langsung (indirect labour) d an pemeliharaan (repair and maintance), $\mathrm{s}$ erta biaya listrik, telpon dan air.

Supriyono (2010) menyatakan t erdapat dua metode yang dapat digunakan d alam pengumpulan harga pokok produksi. $\mathrm{P}$ ertama adalah metode harga pokok pr oduksi berdasarkan pesanan (job order co sting) dan yang kedua metode harga po kok produksi berdasarkan proses ( $p r$ ocess cost). Metode harga pokok pe sanan merupakan salah satu dari metode pe ngumpulan harga pokok produksi yang $\mathrm{m}$ ana proses produksinya berdasarkan pe sanan dari konsumen. "Metode harga po kok pesanan dapat diartikan sebagai suatu sistem akuntansi biaya perpetual yang menghimpun biaya menurut pekerjaan-pekerjaan (jobs) tertentu" (Dunia, 2012:54), sedangkan menurut Sinarwati ( 2013: 63) "metode harga pokok pesanan a dalah metode pengumpulan harga pokok di mana biaya dikumpulkan untuk setiap $p$ esanan atau kontrak jasa secara terpisah, d an setiap pesanan atau kontrak dapat di pisahkan identitasnya. Jumlah biaya $\mathrm{pr}$ oduksi setiap pesanan akan dihitung pada $s$ aat pesanan selesai".

Metode harga pokok proses adalah metode pengumpulan harga pokok produk dimana biaya dikumpulkan untuk setiap satuan waktu tertentu, misalnya bulan, $t$ riwulan, semester, tahun. Produk yang d ihasilkan bersifat homogen, bentuk produk s tandar, dan tidak tergantung spesifiasi y ang diminta oleh pembeli. Contoh $p$ erusahaan yang menghasilkan produk at au jasa atas dasar proses adalah pabrik se men, kertas, petrokimia, tekstil, pe nyulingan minyak mentah, $\mathrm{PN}$, air minum, pe rusahaan angkutan dan lain sebagainya

Karakteristik harga pokok pesanan yaitu, kegiatan produksi dilakukan atas dasar pesanan, sehingga bentuk barang/ produk tergantung pada spesifikasi pesanan. Proses produkinya terputu putus, tergantung ada tidaknya pesanan

yang diterima, biaya produksi dikumpulkan u ntuk setiap pesanan sehingga perhitungan $t$ otal biaya produksi dihitung pada saat pesa nan selesai. Biaya per unit adalah den gan membagi total biaya produksi dengan $t$ otal unit yang dipesan, pengumpulan bi aya produksi dilkukan dengan membut $k$ artu harga pokok pesanan yang berfu ngsi sebagai pembantu biaya yang me muat informasi umum seperti nama peme san, jumlah dipesan, tanggal pesanan dan tanggal diselesaikan, informasi biaya ba han baku, biaya tenaga kerja langsungdan bi aya overhead pabrik yang ditentukan dimu ka, penentuan harga pokok produk per $u$ nit produk dilakukan setelah produk pesan an yang bersangkutan selesai dikerjak an dengan membagi harga pokok prod uk pesanan dengan jumlah unit produk ya ng diselesaikan. 
Terdapat lima manfaat informasi harga pokok pesanan (Job Order Costing) menurut Widilestariningtiyaas (2012) yaitu menentukan harga jual yang akan dibebankan kepada pemesan, mempertimbangkan penolakan atau penerimaan pesanan, mematau realisasi biaya, menghitung laba atau rugi pesanan tiap bruto, dan menentukan harga pokok persedian produk jadi dan produk dalam proses yang disajikan dalam neraca.

Perhitungan harga pokok pesanan harus tepat dan benar sehingga harga jual yang ditetapkan optimal. Penetapan harga j ual yang benar dilakukan sebagai usaha untuk mendapatkan laba yang sesuai dengan yang diinginkan. Untuk memudahkan perhitungan harga pokok produksi tiap pesanan, maka digunakan kartu harga pokok pesanan (job order cost sheet). Kartu harga pokok pesanan digunakan untuk mencatat pemakaian biaya bahan, biaya tenaga kerja, dan pembebanan biaya overhead pabrik ke pesanan yang bersangkutan.

Menurut Witjaksono (2013) ada tujuh t ahapan dalam melakukan kalkulasi biaya $b$ erdasarkan pesanan yaitu tahap mengidentifikasi objek. -objek biaya, mengidentifikasi biaya

langsung dari pesanan, memilih dasar alo kasi biaya tidak langsung, mengidentifikasi $b$ iaya.

-biaya tidak langsung yang dihubungkan de ngan setiap dasar pembebanan biaya, men ghitung tarif biaya overhead pabrik, mengh itung biaya tidak langsung yang dibebank an kesuatu pesanan, dan menghitung biaya yang dibebankan kepada produk ter masuk biaya langsung.

Di dalam sistem biaya berdasarkan pesanan, produksinya hanya akan dilakukan jika perusahaan menerima pesanan dari pembeli dan mengumpulkan harga pokok produksinya dengan menentukan metode harga pokok pesanan. Didalam menentukan biaya pokok pesanan, setiap pesanan merupakan satu kesatuan akuntansi untuk setiap bahan baku, upah langsung dan overhead pabrik. Semua elemen biaya produksi seperti biaya bahan baku, upah langsung dan biaya overhead pabrik dikerjakan sesuai pesanan dari konsumen.

Biaya overhead pabrik merupakan biaya yang paling komplek, untuk keadilan dan ketelitian pembebanan harus digunakan tarip biaya overhead pabrik yang ditentukan di muka, alasan pemakaian tarip pembebanan yaitu adanya biaya overhead yang timbul setelah aktivitas berlalu, adanya biaya yang baru dapat dihitung pada akhir periode, misalnya penyusutan, biaya listrik. Biaya ini apabila dibebankan pada pesanan saat dapat dihitung berakibat menjadi tidak teliti atau adil, dan adanya biaya yang terjadi hanya pada interval waktu tertentu misalnya Ipeda, setahun dibayar sekali atau dicicil dua kali, oleh karena itu untuk membebankan biaya overhead pabrik kepada pesanan harus digunakan tarip yang ditentukan dimuka.

Srada Lamp's merupakan produsen I ampion yang melakukan kegiatan produksi berdasarkan pesanan, sebagian besar pemesan berasal dari luar negeri seperti, Amerika, Spanyol, Prancis, jepang, Italia, Australia, dan beberapa negara lainnya. Jenis produk yang dihasilkan Srada Lamp's yaitu lampion berukuran kecil $(50 \mathrm{~cm} \times 15$ $\mathrm{cm})$, lampion berukuran sedang $(70 \mathrm{~cm} \times 15$ $\mathrm{cm}$ ), lampion dua lampu, dan lampion 3 I ampu. Produk yang dihasilkan Srada Lamp's berbahan dasar fiber dan arbot. Harga jual produk ditetapkan sebelum proses produksi dilakukan. Penetapan harga jual ini, memiliki peranan penting dalam transaksi penjualan karena suatu pesanan dinyatakan diterima atau ditolak setelah adanya kesepakatan harga antara konsumen dan produsen.

Pesanan Srada Lamp's memiliki spesifikasi yang berbeda antara pesanan yang satu dengan pesaan yang lainnya, sehingga menimbulkan permasalahan dalam penetapan harga jual produk. Harga jual produk produk ditetapkan apabila informasi harga pokok tiap produk diketahui. Perhitungan harga pokok pada Srada Lamp's masih dilakukan dengan cara konvensional, sehingga ada biaya yang $t$ idak dihitung terutama biayabiaya yang masuk ke dalam biaya overh ead pabrik. 
Selain itu, penggunaan bahan baku yang masih tersisa yang digunakan untuk memproduksi produk lain tidak dicantumkan dan dibebankan ke produk sebelumnya.

Dari permasalahan tersebut, peneliti $t$ ertarik untuk melakukan penelitian yang $d$ ituangkan dalam judul " Analisis Metode $\mathrm{J}$ ob Order Costing dalam Menentukan $\mathrm{H}$ arga Pokok Produksi pada Srada Lamp's". B erdasarkan uraian di atas maka tujuan

penelitian ini adalah untuk mengetah ui unsur perhitungan harga pokok produksi

yang dilakukan Srada Lamp's selama i ni, perhitungan harga pokok produksi dengan penerapan metode job order cos ting pada Srada Lamp's, dan untuk me ngetahui apakah ada perbedaan perhitunga $\mathrm{n}$ harga pokok produksi yang digunakan Srada Lamp's selama ini dengan perhitunga $n$ yang dilakukan berdasarkan metode job order costing.

\section{METODE}

Penelitian ini menggunakan pendekatan penelitian deskriptif kuantitatif. Silalahi (2003:28) mengatakan "penelitian d eskriptif kuantitatif merupakan penelitian ya ng berusaha untuk menuturkan pe mecahan masalah atau penyajian tahap ya ng lebih lanjut dari hasil observasi berupa dat a yang kemudian dianalisis sampai pada pe mberian interprestasi". Data yang dih asilkan berupa data terkait dengan per hitungan harga pokok produksiber dasarkan metode job order costing unt uk penentuan harga pokok produksi. Pen eliti melakukan observasi awal tentang pene tapan harga pokok produksi pada Srad a Lamp's tahun 2017. data yang telah dida pat kemudian dianalisis dan ditarik kesi mpulan.

Lokasi penelitian ini dilakukan dit empat produksi Srada Lamp's, tepatnya di Jalan Raya Ceking, Tegaglalang, Gianyar, Bali.

Subjek penelitian ini adalah Srada Lamp's, sedangkan yang menjadi objek penelitian adalah penentuan harga pokok produksi pada Srada Lamp's.

Berdasaran jenisnya, data yang digunakan dalam penelitian ini adalah data kuantitatif, yang bertujuan untuk mengetahui proses serta hasil darip enentuan biaya produksi tafsiran dengan $s$ esungguhnya dari metode harga pokok pe sanan (job order costing metod). Sumber da ta yang digunakan dalam penelitian ini dat a sekunder. Data sekunder adalah data yan $g$ diperoleh dari tangan kedua. Dalam hal ini, data mengenai laporan produksi yang dihasilkan perusahaan.

Metode pengumpulan data yang digunakan dalam penelitian ini adalah metode dokumentasi. Metode doumentasi digunakan peneliti untuk mengetahui perhitungan harga pokok produksi pada Srada Lamp's, baik biaya yang dikeluarkan, maupun bahan yang digunakan dalam memproduksi barang, untuk mengetahui data tersebut dilakukan dengan cara melihat catatan biaya dan bahan yang digunakan dalam proses produksi Srada Lamp's.

Metode analisis data yang digunakan adalah perhitungan dengan menggunakan pengumpulan harga pokok berdasarkan metode job order costing, baik perhitungan biaya bahan baku, tenaga kerja, maupun biaya overhead pabrik.

\section{HASIL DAN PEMBAHASAN Hasil}

Srada Lamp's merupakan produsen I ampion berbahan dasar arbot dan fibber. Produksi lampion dilakukan berdasarkan pesanan dari pelanggan. Ada empat model lampion yang ditawarkan oleh Srada Lamp's kepada pelanggan. Keempat I ampion yang dijadikan sebagai model yaitu, I ampion berukuran kecil $(50 \mathrm{~cm} \times 15 \mathrm{~cm})$, I ampion berukuran sedang $(70 \mathrm{~cm} \times 15 \mathrm{~cm})$, I ampion 2 lampu, dan lampion 3 lampu.

Perhitungan harga pokok produksi pada Srada Lamp's ditentukan dimuka karena harga jual lampion yang ditawarkan kepada pelanggan ditetapkan sebelum proses produksi dilakukan. Perhitungan harga pokok produksi pada Srada Lamp's menggunakan dua unsur biaya yaitu biaya bahan baku dan biaya tenaga kerja langsung (BTKL). Bahan baku yang digunakan untuk memproduksi lampion 
pada Srada Lamp's yaitu arbot, fibber, resin, cat, lampu, stop kontak, lakban, pip a ukuran 3", lem, tinner, premium, da $\mathrm{n}$ amplas. sedangkan biaya tenaga kerja yan g dibebankan adalah biaya tenaga kerj a langsung yang digunakan untu menghasilkan produk. Perhitungan harga pokok produksi pada Srada Lamp's berdasarkan penjumlahan biaya bahan baku dan biaya tenaga kerja langsung. Harga pokok produksi (HPP) pada Srada Lamp's dapat dilihat pada tabel 1 berikut ini

Tabel 1. Harga Pokok Produksi pada Srada Lamp's

\begin{tabular}{|c|c|c|c|c|}
\hline No & Model Produk & $\begin{array}{l}\text { Biaya Bahan } \\
\text { Baku (Rp) }\end{array}$ & BTKL (Rp) & HPP (Rp) \\
\hline 1 & $\begin{array}{l}\text { Lampion berukuran kecil } \\
(50 \mathrm{~cm} \times 15 \mathrm{~cm})\end{array}$ & Rp. $61.879,50$ & $8.000,00$ & Rp. $\quad 69.879,50$ \\
\hline 2 & $\begin{array}{l}\text { Lampıon berukuran } \\
\text { sedang }(70 \mathrm{~cm} \times 15 \mathrm{~cm})\end{array}$ & Rp. $77.477,15$ & Rp. $10.000,00$ & Rp. $87.477,15$ \\
\hline 3 & Lampion 2 lampu & Rp. & & Rp.158.10 \\
\hline 4 & Lampion 3 lampu & Rp.260.562,50 & Rp. $24.000,00$ & Rp.284.562,50 \\
\hline
\end{tabular}

Berdasarkan harga pokok produksi pada tabel 1 diatas dapat diketahui bahwa harga pokok produksi untuk lampion berukuran kecil $(50 \mathrm{~cm} \times 15 \mathrm{~cm}) \mathrm{Rp}$. $69.879,50$ atau jika dibulatkan menjadi $\mathrm{Rp}$. $70.000,00$, lampion berukuran sedang (70 $\mathrm{cm} \times 15 \mathrm{~cm}$ ) Rp. 87.477,15 jika dibulatkan menjadi Rp. 87.500,00, lampion 2 lampu Rp. 158.101,25 jika dibulatkan menjadi 159.000,00, dan harga pokok lampion 3 lampu Rp. 284.562,50 jika dibulatkan menjadi 284.600,00.

Srada Lamp's dalam setiap produksinya bertujuan untuk melayani pesanan yang sifat produksinya terputus-putus. Selesai memproduksi pesanan yang satu dilanjutkan dengan pengolahan pesanan yang lain. Bedasarkan tujuan dari
Srada Lamp's maka peneliti menghitung harga pokok produksi dengan metode job order costing. Metode ini digunakan karena sesuai dengan kegiatan produksi yang dilakukan oleh Srada Lamp's. Model produk yang digunakan dalam perhitungan ini ada empat namun dengan spesifikasinya masing-masing.

Perhitungan dengan Metode job order costing dilakukan dengan mengumpulkan semua biaya yang digunakan untuk memproduksi produk pesanan. Adapun biaya yang digunakan adalah biaya bahan baku, biaya tenaga kerja langsung dan biaya overhead pabrik. Biaya bahan baku berdasarkan motede job order costing pada bulan maret dapat dilihat pada tabel 2 berikut ini.

Tabel 2. Biaya Bahan Baku dengan Metode Job Order Costing pada Bulan Maret 2017

\begin{tabular}{|c|c|c|c|c|c|}
\hline \multirow[b]{2}{*}{ No } & \multicolumn{5}{|c|}{ Spesifikasi } \\
\hline & Jenis produk & $\begin{array}{l}\text { Bentuk } \\
\text { lampion }\end{array}$ & $\begin{array}{l}\text { Jumlah } \\
\text { Pesanan }\end{array}$ & Biaya & Bahan Baku \\
\hline 1 & $\begin{array}{l}\text { Lampion berukuran kecil } \\
\qquad(50 \mathrm{~cm} \times 15 \mathrm{~cm})\end{array}$ & $\begin{array}{c}\text { Bulat } \\
\text { Hati }\end{array}$ & $\begin{array}{l}80 \text { Buah } \\
45 \text { Buah }\end{array}$ & $\begin{array}{l}\mathrm{Rp} \\
\mathrm{Rp}\end{array}$ & $\begin{array}{l}5.472 .300 \\
3.224 .400\end{array}$ \\
\hline 2 & $\begin{array}{l}\text { Lampion berukuran } \\
\text { sedang }(70 \mathrm{~cm} \times 15 \mathrm{~cm})\end{array}$ & $\begin{array}{l}\text { Bulat } \\
\text { Oval }\end{array}$ & $\begin{array}{l}30 \text { Buah } \\
90 \text { Buah }\end{array}$ & Rp & $\begin{array}{l}2.334 .900 \\
7.091 .700\end{array}$ \\
\hline 2 & I amninn ? I amnı। & $\begin{array}{l}\text { Bulat } \\
\text { Oval } \\
\text { Oval }\end{array}$ & $\begin{array}{l}115 \text { Buah } \\
40 \text { Buah } \\
20 \text { Buah }\end{array}$ & $\begin{array}{l}, 00 \\
\overline{R p} \\
\overline{R p}\end{array}$ & $\begin{array}{l}7.174 .250 \\
5.702 .250\end{array}$ \\
\hline 4 & Lampion 3 Lampion & $\begin{array}{l}\text { Kuncup } \\
\text { Bulat }\end{array}$ & $\begin{array}{l}28 \text { Buah } \\
10 \text { Buah }\end{array}$ & $\begin{array}{l}, 00 \\
R p\end{array}$ & 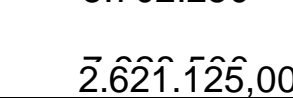 \\
\hline
\end{tabular}


Biaya tenaga kerja langsung dengan mengguakan metode job order costing yang digunakan dalam proses produksi pada
Srada Lamp's dapat dilihat pada tabel 3 berikut ini.

Tabel 3. Biaya Tenaga Kerja dengan Metode Job Order Costing pada tahun 2017

\begin{tabular}{|c|c|c|c|c|c|}
\hline \multirow[b]{2}{*}{ No } & \multirow[b]{2}{*}{ Jenis produk } & \multicolumn{2}{|c|}{ Spesifikasi } & \multirow{2}{*}{ Biaya } & \multirow[b]{2}{*}{$\begin{array}{l}\text { Tenaga Kerja } \\
(\mathrm{Rp})\end{array}$} \\
\hline & & $\begin{array}{l}\text { Bentuk } \\
\text { lampion }\end{array}$ & Jam Kerja & & \\
\hline \multirow[t]{2}{*}{1} & Lampion berukuran kecil & Bulat & 56 Jam & $\mathrm{Rp}$ & $640.000,00$ \\
\hline & $(50 \mathrm{~cm} \times 15 \mathrm{~cm})$ & Hati & 40 Jam & $\mathrm{Rp}$ & 0,00 \\
\hline \multirow[t]{2}{*}{2} & Lampion berukuran & Bulat & 48 Jam & $\mathrm{Rp}$ & 00,00 \\
\hline & sedang $(70 \mathrm{~cm} \times 15 \mathrm{~cm})$ & Oval & 64 Jam & $\mathrm{Rp}$ & $900.000,00$ \\
\hline \multirow{3}{*}{3} & I amning 2 I amn & Bulat & 120 Jam & $\mathrm{Rp}$ & $1.840 .000,00$ \\
\hline & Lampion 2 Lampu & Oval & 64 Jam & $\mathrm{Rp}$ & $640.000,00$ \\
\hline & & Oval & 52 Jam & $\mathrm{Rp}$ & $480.000,00$ \\
\hline \multirow[t]{2}{*}{4} & Lampion 3 Lampion & Kuncup & 64 Jam & $\mathrm{Rp}$ & $672.000,00$ \\
\hline & & Bulat & $24 \mathrm{Jam}$ & $\mathrm{Rp}$ & $240.000,00$ \\
\hline
\end{tabular}

Biaya overhead pabrik dengan menggunakan metode job order costing pada bulan Maret 2017 dapat dilihat pada tabel 4 berikut ini.

Tabel 4. Biaya Overhead Pabrik dengan Metode Job Order Costing pada bulan Maret 2017

\begin{tabular}{|c|c|c|c|c|c|}
\hline No & Jenis produk & \multicolumn{2}{|r|}{ Spesifikasi } & \multicolumn{2}{|c|}{$\begin{array}{l}\text { Biaya Overhead } \\
\text { Pabrik (Rp) }\end{array}$} \\
\hline \multirow{4}{*}{1} & \multirow{4}{*}{$\begin{array}{l}\text { Lampion berukuran } \\
\text { kecil }(50 \mathrm{~cm} \times 15 \mathrm{~cm})\end{array}$} & & Listrik & Rp. & $64.000,00$ \\
\hline & & Bulat & $\begin{array}{c}\text { Air } \\
\text { Rep Pemeliharaan Aktiva Tetan }\end{array}$ & $\mathrm{Rp}$ & 14.400, \\
\hline & & & $\begin{array}{l}\text { Rep. Pemennaaraan AktIva I letap } \\
\text { Listrik }\end{array}$ & $\mathrm{Rp}^{-}$ & 36.000 \\
\hline & & Hati & $\begin{array}{l}\text { Air Rep.Pemeliharaan Aktiva Te } \\
\text { tap Listrik }\end{array}$ & $\begin{array}{l}00 \\
R p \\
00 \mathrm{Rp}\end{array}$ & $\begin{array}{l}81.000 \\
22.500\end{array}$ \\
\hline \multirow{4}{*}{2} & \multirow{4}{*}{$\begin{array}{l}\text { Lampion berukuran } \\
\text { sedang }(70 \mathrm{~cm} \times 15 \\
\qquad \mathrm{cm})\end{array}$} & Bulat & $\begin{array}{c}\text { Air } \\
\text { Rep. Pemeliharaan Aktiva Tetap }\end{array}$ & $\begin{array}{l}\mathrm{Rp}^{-} \\
, 00\end{array}$ & 5.400 \\
\hline & & & Listrik & $\mathrm{Rp}$ & 15.000, \\
\hline & & Oval & Air & $00 \mathrm{Rp}$ & 72.000, \\
\hline & & & Rep. Pemeliharaan Aktiva Tetap & $\begin{array}{l}00 R p \\
00 R p\end{array}$ & $\begin{array}{l}16.200 \\
45.000\end{array}$ \\
\hline \multirow{8}{*}{3} & \multirow{4}{*}{ Lampion 2 Lampu } & \multirow[t]{2}{*}{ Bulat } & Air & $00 \mathrm{Rp}$ & 92.000 \\
\hline & & & $\begin{array}{c}\text { Kep. remeınaraan Aкııva ı етар } \\
\text { Listrik }\end{array}$ & $\hat{n}^{\text {nn }}$ & $33.3000,0$ \\
\hline & & \multirow[t]{3}{*}{ Oval Ov } & Air & $\mathrm{Rp}$ & 7.200 \\
\hline & & & Rep. Pemeliharaan Aktiva Tetap &, $00 \mathrm{Rp}$ & 20.000 \\
\hline & \multirow{9}{*}{ Lampion 3 Lampu } & & Listrik &, $00 \mathrm{Rp}$ & 16.000 \\
\hline & & \multirow[t]{3}{*}{ al Kunc } & Air &, $00 \mathrm{Rp}$ & 3.600 \\
\hline & & & Rep. Pemeliharaan Aktiva Tetap &, $00 \mathrm{Rp}$ & 10.000 \\
\hline & & & Listrik &, $00 \mathrm{Rp}$ & 22.400 \\
\hline \multirow[t]{5}{*}{4} & & \multirow[t]{3}{*}{ up } & Air Rep.Pemeliharaan Aktiva Te &, $00 \mathrm{Rp}$ & 5.040 \\
\hline & & & tap Listrik &, $00 \mathrm{Rp}$ & 14.000 \\
\hline & & & Air &, $00 \mathrm{Rp}$ & 8.000 \\
\hline & & \multirow[t]{2}{*}{ Bulat } & &, $00 \mathrm{Rp}$ & 1.800 \\
\hline & & & Rep. Pemeliharaan Aktiva Tetap & $\mathrm{Rp}$ & $5.000,00$ \\
\hline
\end{tabular}


Berdasarkan perhitungan di atas, harga pokok produksi dengan metode job order costing pada bulan Maret 2017 dapat dilihat pada tabel 5 berikut ini.

Tabel 5. Harga Pokok Produksi dengan Menggunakan Metode Job Order Costing

\begin{tabular}{|c|c|c|c|c|c|}
\hline \multirow{3}{*}{$\frac{\text { No }}{1}$} & \multirow{4}{*}{$\begin{array}{l}\text { Jenis produk } \\
\text { Lampion beruku } \\
\text { ran kecil }(50 \mathrm{~cm}\end{array}$} & \multicolumn{2}{|c|}{ Spesifikasi } & \multirow{4}{*}{$\begin{array}{c}\text { Harga Pokok } \\
\text { Produksi } \\
\text { Rp.6.230.700,00 }\end{array}$} & \multirow{3}{*}{$\begin{array}{c}\text { HPP Per } \\
\text { Prodyk (Rp) } \\
\text { Rp. } 77.883,75\end{array}$} \\
\hline & & Bentuk & Jumlah & & \\
\hline & & lapposien & Besanah & & \\
\hline & & & & & \\
\hline \multirow{3}{*}{2} & $\begin{array}{l}\text { x 15 } \\
\mathrm{cm})\end{array}$ & Hati & 45 Buah & Rp.3.723.900,00 & Rp. $82.753,33$ \\
\hline & Lampion & Bulat & 30 Buah & Rp.2.679.300,00 & Rp. $89.310,00$ \\
\hline & $\begin{array}{l}\text { sedang }(70 \mathrm{~cm} \\
\quad \times 15 \mathrm{~cm})\end{array}$ & Oval & 90 Buah & Rp.8.124.900,00 & Rp. $90.276,67$ \\
\hline \multirow{2}{*}{$\mathbf{2}$} & Lampion 2 & Bulat & 115 Buah & Rp.22.611.225,00 & Rp. $196.619,35$ \\
\hline & Lampu & Oval & 40 Buah & Rp. $\quad 7.873 .450,00$ & Rp. $196.836,25$ \\
\hline \multirow{3}{*}{4} & Lampion 3 & Oval & 20 Buah & Rp. 6.211.850,00 & Rp. $310.597,00$ \\
\hline & Lampion & Kuncup & 28 Buah & Rp. 8.641.940,00 & Rp. $308.640,72$ \\
\hline & & Bulat & 10 Buah & Rp. 2.875.925,00 & Rp. $287.592,50$ \\
\hline
\end{tabular}

Perhitungan harga pokok yang dilakukan oleh peneliti dan produsen Srada Lamp's pada penentuan harga pokok produksi lampion yang diproduksi oleh Srada Lamp's memiiki perbedaan adapun perbedaan perhitungan sangat terlihat pada produk yang diproduksi, dimana Srada Lamp's menggunakan empat produk tanpa memperhatikan spesifikasi dari masingmasing produk, sedangkan peneliti menghitung berdasarkan metode job order costing. Pada perhitungan metode job order costing spesifikasi barang yang diproduksi diperhitungkan secara rinci, selain itu perbedaan perhitungan harga pokok produksi pada Srada Lamp's ini dikarenakan perhitungan yang dilakukan dengan menggunakan metode job order costing, menghitung biaya bahan baku per pesanan, biaya tenaga kerja langsung, dan biaya overhead pabrik yang dibebankan dimuka pada setiap produk pesanan. sedangkan produsen Srada Lamp's menghitung harga pokok produksi pada Srada Lamp's secara konvensional dan berdasarkan pengalaman masa lalunya. Perbedaan tersebut dapat dilihat pada tabel 6 berikut ini.

Tabel 6. Perbedaan Perhitungan Harga Pokok Produksi

\begin{tabular}{|c|c|c|c|c|}
\hline No & Jenis produk & $\begin{array}{l}\text { HPP Srada } \\
\text { Lamp's }\end{array}$ & $\begin{array}{l}\text { Bentuk } \\
\text { lampion }\end{array}$ & $\begin{array}{l}\text { HPP per } \\
\text { Produk }\end{array}$ \\
\hline 1 & $\begin{array}{l}\text { Lampion berukuran kecil (50 } \\
\qquad \mathrm{cm} \times 15 \mathrm{~cm})\end{array}$ & Rp. $69.879,50$ & $\begin{array}{l}\text { Bulat } \\
\text { Hati }\end{array}$ & $\begin{array}{l}\text { Rp. } 77.883,75 \\
\text { Rp. } 82.753,33\end{array}$ \\
\hline 2 & $\begin{array}{l}\text { Lampion berukuran sedang } \\
\quad(70 \mathrm{~cm} \times 15 \mathrm{~cm})\end{array}$ & Rp. $87.477,15$ & $\begin{array}{l}\text { Bulat } \\
\text { Oval }\end{array}$ & $\begin{array}{l}\text { Rp. } 89 \cdot 310,00 \\
\text { Rp. } 90 \cdot 276,67\end{array}$ \\
\hline 3 & Lampion 2 Lampu & Rp.158.101,25 & $\begin{array}{l}\text { Bulat } \\
\text { Oval } \\
\text { Oval }\end{array}$ & $\begin{array}{l}\text { Rp. } 196.619,35 \\
\text { Rp. } 196.836,25 \\
\text { Rp. } 310.597,00\end{array}$ \\
\hline 4 & Lampion 3 Lampion & Rp.284.532,50 & $\begin{array}{c}\text { Kuncup } \\
\text { Bulat }\end{array}$ & $\begin{array}{l}\text { Rp.308.640,72 } \\
\text { Rp.287.592,50 }\end{array}$ \\
\hline
\end{tabular}




\section{PEMBAHASAN}

Berdasarkan hasil olahan data pada hasil penelitian di atas, perhitungan harga pokok produksi dapat dibandingkan dengan teori yang ada. Menurut teori yang dikemukakan oleh Supriyono (2010) harga pokok pesanan dikumpulkan untuk setiap pesanan sesuai dengan biaya yang dinikmati pada setiap pesanan, jumlah biaya produksi setiap pesanan akan dihitung pada saat pesanan selesai. Biaya produksi yang dikumpulkan untuk setiap pesanan bertujuan agar harga pokok pesanan dapat dihitung dengan relatif teliti dan adil.

Biaya yang dibebankan untuk setiap pesanan hanya menggunakan sistem harga pokok historis untuk baya bahan baku dan biaya tenaga kerja langsung, sedangkan untuk biaya overhead pabrik dihitung menggunakan tarif yang dihitung dimuka.

Perhitungan harga pokok produksi pada Srada Lamp's hanya menghitung biaya bahan baku dan biaya tenaga kerja I angsung tanpa menghitung biaya overhead $p$ abrik sehingga harga pokok yang $d$ idapatkan lebih rendah dari perhitungan $h$ arga pokok dengan menggunakan metode $\mathrm{j}$ ob order costing. Penentuan harga pokok $p$ roduksi dengan metode job order costing mempertimbangkan spesifikasi produk yang diproduksi oleh Srada lamp's, dimana masing.

-masing produk memiliki harga pokok $t$ ersendiri. Hasil penelitian ini sejalan dengan

hasil penelitian terdahulu yang dilakuk an oleh Fardhani (2016) bahwa Perhitu ngan harga pokok produksi dengan menggu nakan metode job order costing memiliki

nilai lebih tinggi dibandingkan dengan pe rhitungan menggunakan metode perusahaa n.

Perbedaan perhitungan harga pokok produksi pada Srada Lamp's dan Metode j ob order costing ini dikarenakan perhitungan yang dilakukan dengan menggunakan metode job order costing, menghitung biaya bahan baku per pesanan, $b$ iaya tenaga kerja langsung, dan biaya o verhead pabrik yang dibebankan dimuka pa da setiap produk pesanan. Hal ini sej alan dengan pendapat yang dikemukakan oleh Sinarwati (2013) bahwa harga pokok pesanan adalah metode pengumpulan harga pokok produksi dimana biaya dikumpulkan untuk setiap pesanan atau kontrak dan dapat dibedakan identitasnya.

\section{SIMPULAN DAN SARAN Simpulan}

Berdasarkan hasil penelitian yang dilakukan pada Srada Lamp's maka dapat dibuat simpulan yaitu perhitungan harga pokok produksi yang dilakukan oleh Srada Lamp's hanya menghitung biaya bahan baku dan biaya tenaga kerja langsung pada produk pesanan, maka harga pokok produksi untuk lampion berukuran kecil (50 $\mathrm{cm} \times 15 \mathrm{~cm})$ Rp. 64.496,50 atau jika dibulatkan menjadi Rp. 64.700,00, lampion berukuran sedang $(70 \mathrm{~cm} \times 15 \mathrm{~cm}) \mathrm{Rp}$. $86.580,00$ jika dibulatkan menjadi $\mathrm{Rp}$. $86.600,00$, lampion 2 lampu Rp. 189.711,50 jika dibulatkan menjadi 189.800,00, dan harga pokok lampion 3 lampu $R p$. 288.845,26 jika dibulatkan menjadi $288.900,50$.

Perhitungan harga pokok produksi menggunakan metode job order costing, maka harga pokok produksi untuk lampion berukuran kecil $(50 \mathrm{~cm} \times 15 \mathrm{~cm})$ berbentuk bulat Rp. 76.891,25 dan bentuk lampion love Rp. 80.120,00. Lampion ukuran sedang $(70 \mathrm{~cm} \times 15 \mathrm{~cm})$ terbagi menjadi dua yaitu bentuk lampion bulat dan oval, untuk lampion berbentuk bulat $\mathrm{Rp}$. $87.880,00$, dan bentuk oval Rp. 88.824,44. Lampion 2 lampu terbagi menjadi 2 yaitu bulat dan oval. Hpp bentuk bulat $\mathrm{Rp}$. 184.295.90 dan bentuk oval Rp. 183.831,30 sedangkan untuk lampion 3 lampu dibagi menjadi 3 bentuk yaitu bentuk oval, kuncup, dan bulat. Lampion berbentuk oval Rp 309.612.50, bentuk kuncup Rp. 307.696.40, dan lampion berbentuk bulat $\mathrm{Rp}$. 286.562.50.

Perbedaan hasil perhitungan harga pokok produksi pada Srada Lamp's dengan perhitungan harga pokok produksi dengan metode job order costing yaitu lampion ukuran kecil $(50 \mathrm{~cm} \times 15 \mathrm{~cm})$ berbentuk bulat Rp. 11.930,75, bentuk love Rp. 
15.159,50. Lampion ukuran sedang $(70 \mathrm{~cm}$ $x 15 \mathrm{~cm}$ ) bentuk bulat $\mathrm{Rp} .1 .300,00$ bentuk oval Rp. 2.244,44. untuk lampion 2 lampu bentuk bulat Rp. $5.415,60$, bentuk oval $R$ p.

5.880,20. sedangkan lampion 3 lampu bentuk bulat Rp. 2.282,76 bentuk kuncup Rp. 18.851,14 bentuk oval Rp. 20.767,24

\section{Saran}

Berdasarkan simpulan di atas, perhitungan harga pokok produksi pada Srada Lamp's lebih rendah dibandingkan dengan perhitungan harga pokok produksi dengan menggunakan metode job order costing oleh karena itu peneliti menyarankan dalam menentukan harga pokok produksi, sebaiknya Srada Lamp's menerapkan metode job order costing. Penentuan harga pokok produksi dengan menggunakan metode job order costing I ebih teliti karena perhitungan dengan metode ini dilakukan dengan mengumpulkan semua biaya yang digunakan untuk memproduksi produk, sehingga semua biaya yang dikeluarkan untuk memproduksi produk pada Srada Lamp's dapat terakumulasi ke dalam produk yang dihasilkan.

\section{DAFTAR PUSTAKA}

Bustami, Bastian dan Nurlela. 2009. Akuntansi Biaya. Jakarta: Mitra Wacana

Carter, William K. 2009. Akuntansi Biaya. Jakarta: Salemba Empat

Daljono. 2011. Akuntansi Biaya. Semarang: Universitas Diponogoro

Dewi, S Prima dan S.B. kristanto. 2015. Akuntansi Biaya. Bogor: In Media.

Dunia, A. Firdaus dan W. Abdullah. 2012. Akuntansi Biaya. Jakarta: Salamba Empat.

Fardhani, Nizar. 2016. Evaluasi penerapan Job Order Costing Methode dalam Penentuan Harga Pokok Produksi pada CV. Visual Komunika Mandiri. Skripsi (tidak diterbitkan) Jurusan
Akuntansi. Universitas Sam Ratulangi Manado

Halim, Abdul.2001. Manajemen Keuangan Daerah. Jakarta: Salemba Empat

Hansen, Don, dkk. 2003. Akuntani Biaya. Jakarta: Salemba Empat

Sinarwati, Ni Kadek. 2013. Akuntansi Biaya. Singaraja: Universitas pendidikan Ganesh

Supriyono, RA. 2010. Akuntansi Biaya: Pengumpulan Biaya dan Penentuan Harga Pokok. Yogyakarta: BPFE

Wildilestarinintyas,Ony, dkk. 2012. Akuntansi Biaya. Yogyakarta: Graha I Imu.

Witjaksono, Armanto. 2013. Akuntansi Biaya. Yogyakarta: Graha IImu. 